\title{
PENGARUH STRUKTUR KEPEMILIKAN BANK DAN PENDAPATAN PEMBIAYAAN TERHADAP PROFITABILITAS BANK UMUM SYARIAH DI INDONESIA
}

\author{
Hamdi Agustin, Yusrawati \& Nawarti Bustamam \\ Fakultas Ekonomi (FE), Universitas Islam Riau (UIR) \\ Email:hamdiagustin@eco.uir.ac.id,yusrawati@eco.uir.ac.id,nawartibustamam@eco.uir.ac.id
}

\begin{abstract}
ABSTRAK
Tujuan penelitian ini untuk mengetahui pengaruh struktur kepemilikan bank dan pendapatan mudharabah dan pendapatan musyarakah terhadap profitabilitas yang diukur dengan Return On Asset (ROA) pada bank umum syariah di Indonesia. Sampel yang digunakan adalah perbankan syariah dan observasi yang dilakukan dalam penelitian ini berjumlah 96 dengan pendekatan laporan triwulan satu sampai keempat periode 2015-2018. Penelitian ini menggunakan data panel dengan metode analisis regresi. Hasil penelitian menunjukkan bahwa struktur kepemilikan tidak berpengaruh terhadap Return On Asset. Pendapatan mudharabah berpengaruh positif dan signifikan terhadap Return On Asset. Sedangkan pendapatan musyarakah berpengaruh negatif dan signifikan terhadap Return On Asset.
\end{abstract}

Kata kunci : Mudharabah, Musyarakah, Return on Asset, Struktur Kepemilikan dan Bank Syariah.

\begin{abstract}
The purpose of this study was to determine the effect of ownership structure, mudharabah income and musyarakah income on profitability measured by Return on Asset (ROA) in Islamic commercial banks in Indonesia. The sample used is Islamic banking and the observations made in this study amounted to 96 with the reporting approach for quarter of the 2015-2018 period. This study uses panel data with regression analysis method. The results showed that the ownership structure has no effect on Return on Assets. Mudharabah income has a positive and significant effect on Return on Assets. Meanwhile, musyarakah income has a negative and significant effect on Return on Assets.
\end{abstract}

Keywords : Mudharabah, Musharakah, Return on Asset, Ownership Structure and Islamic Banking. 


\section{PENDAHULUAN}

Di antara bentuk pembiayaan yang dilakukan oleh bank umum syariah adalah pembiayaan berdasarkan prinsip bagi hasil (mudharabah) dan pembiayaan berdasarkan prinsip penyertaan modal (musyarakah). Mudharabah yang berasal dari kata dharb adalah suatu akad kerja sama antara dua belah pihak, dimana dari pihak pertama si pemilik dana (shahibul maal) mempercayakan modalnya kepada pihak kedua yaitu si pengelola (mudharib). Pada akad ini beresiko tinggi dikarenakan usaha yang akan dijalankan si pengelola belum tentu berhasil. Pada akad musyarakah yakni akad kerja sama antara dua pihak atau lebih dimana semua pihak menanamkan dana atau modalnya pada usaha yang akan dikelola, dimana keuntungan dan kerugian akan ditanggung bersama (Antonio, 2007).

Pembiayaan yang diberikan bank umum syariah bertujuan untuk mendapatkan keuntungan bank dimana tingkat keuntungan tersebut yang dapat diukur dengan rasio Return On Asset (ROA). Rasio ROA merupakan salah satu pengukur kinerja keuangan di perbankan. Profitabilitas yang meningkat menunjukkan kinerja bank yang baik. Berikut ini sajikan data kinerja bank umum syariah di Indonesia.

Tabel 1. Pendapatan Mudharabah, Musyarakah dan ROA Perbankan Syariah 2015-2018 (dalam Miliar Rupiah)

\begin{tabular}{cccc}
\hline Tahun & Mudharabah & Musyarakah & ROA (\%) \\
\hline 2015 & 1.120 & 4.641 & 0,49 \\
\hline 2016 & 1.008 & 4.649 & 0,63 \\
\hline 2017 & 893 & 5.207 & 0,63 \\
\hline 2018 & 717 & 5.421 & 1,28 \\
\hline
\end{tabular}

Sumber : Statistik Perbankan Syariah (2019)

Tabel diatas menunjukkan bahwa pendapatan bagi hasil mudharabah pada tahun 2015 sampai tahun 2018 mengalami penurunan, dengan nilai secara berturutturut 1.120 Miliar Rupiah, 1.008 Miliar Rupiah, 893 Miliar Rupiah, dan 717 Miliar Rupiah. Berbeda dengan pendapatan akad mudharabah, pada pendapatan akad musyarakah mengalami kenaikan dari tahun 2015 sampai dengan tahun 2018 berturut-turut dengan nilai sebesar 4.641 Miliar Rupiah, 4.649 Miliar Rupiah, 5.207 Miliar Rupiah, dan 5.421 Miliar Rupiah. Sedangkan pada tabel profitabilitas Return On Asset pada tahun 2015 dan 2016 mengalami kenaikan secara berturut-turut dengan nilai sebesar $0,49 \%$ dan $0,63 \%$ tetapi pada tahun 2017 tetap stabil dengan nilai sebesar $0,63 \%$, kemudian kembali mengalami kenaikan pada tahun 2018 dengan nilai sebesar $1,28 \%$. Data tabel di atas menunjukkan bahwa kecenderungan pendapatan pembiayaan mudharabah turun dengan sebaliknya pada pendapatan musyarakah cenderung meningkat dan ROA juga cenderung meningkat. Hal ini menjadi suatu permasalahan pada pendapatan mudharabah dimana kemungkinan pendapatan pembiayaan mudharabah tidak efektif sehingga kebijakan pembiayaan dapat dirubah menjadi pembiayaan musyarakah.

$\begin{array}{crr}\text { Beberapa } & \text { penelitian } & \text { telah } \\ \text { mendokumentasikan } & \text { bahwa } & \text { bank }\end{array}$
pemerintah memiliki aset yang lebih rendah, biaya yang lebih tinggi dan kualitas aset yang lebih rendah daripada bank swasta (Berger et al., 2004; Berger et al., 2005; dan Micco et al., 2004). Selain itu, Cornett et al., (2010) menyatakan bahwa bank pemerintah memiliki pendapatan rendah, modal kecil dan pinjaman berisiko tinggi. La Porta et al., (2002) menunjukkan bahwa bank yang dikendalikan oleh kepemilikan lokal atau 
domestik biasanya memiliki saham yang besar di perusahaan non keuangan dan cenderung meminjamkan uang kepada perusahaan yang berasosiasi dengan mereka meskipun pinjaman tersebut tidak kompeten (berisiko tinggi).

Berdasarkan pada kondisi pendapatan pembiayaan mudharabah dan musyarakah pada bank umum syariah di Indonesia yang mungkin saja dipengaruhi oleh struktur kepemilikan bank oleh pemerintah dan swasta sehingga terjadi perbedaan kebijakan pada pembiayaan. Dengan demikian, pada penelitian ini mencoba mengkaji pengaruh struktur kepemilikan bank yang dimiliki pemerintah dan swasta dan pendapatan mudharabah dan pendapatan musyarakah terhadap profitabilitas yang diukur dengan Return On Asset (ROA). Tujuan penelitian ini untuk menganalisis pengaruh struktur kepemilikan bank, pendapatan mudharabah dan musyarakah terhadap profitabilitas bank umum syariah di Indonesia.

\section{TINJAUAN PUSTAKA}

\section{a. Mudharabah}

Mudharabah merupakan akad kerjasama antara dua pihak yang mempunyai dan menyiapkan dana untuk membiayai dan menjalankan suatu usaha. Dalam fiqh muamalah penyalur dana (modal) dikenal dengan shahibul maal dan pengelola disebut mudharib. Tata cara dan pembagian keuntungan disepakati pada awal akad mudharabah ingin disahkan, dan suatu usaha tersebut tentu yang berdasarkan Islami atau sesuatu yang jauh dari riba.

Mudharabah tentu memiliki manfaat dan resiko dalam pengaplikasiannya, berikut adalah beberapa manfaat dari mudharabah:

a. Jika bisnis yang dijalankan nasabah berjalan lancar, maka bank juga akan menikmati hasil dari keuntungan yang meningkat.

b. Hasil dari bisnis tersebut disesuaikan untuk membayarkan bagi hasil kepada nasabah, karena bank tidak wajib untuk membayarnya secara tetap.

c. Arus kas bisnis disesuaikan untuk pemulangan pokok pembiayaan, jadi nasabah tidak merasa berat.

d. Bank harus memilih secara hati-hati untuk melihat apakah bisnis yang akan dijalankan tersebut sesuai dengan syariat/halal atau tidak.

e. Mudharabah ini berbeda dengan sistem bunga, bank akan tetap menagih kepada nasabah meskipun untung atau rugi.

Sedangkan resiko yang akan terjadi dalam penyaluran dana bagi hasil mudharabah ini adalah :

a. Nasabah bisa saja tidak menggunakan dana itu dengan baik dan tidak seperti perjanjian di awal akad.

b. Nasabah melakukan kesalahan yang disengaja sehingga membuat kerugian dalam bisnis tersebut.

c. Keuntungan bisa disembunyikan oleh nasabah yang tidak jujur, sehingga yang diberikan kepada bank bukanlah keuntungan yang sebenarnya.

\section{b. Musyarakah}

Musyarakah merupakan akad kerja sama yang dilakukan antara dua orang atau lebih yang sama-sama memiliki modal untuk membuka suatu usaha tertentu yang sesuai syariah, dan kesepakatan pembagian keuntungan dan bersama-sama bertanggung jawab dengan resiko yang akan terjadi.

Dalam melakukan akad musyarakah, tentu ada kekurangan dan kelebihan dalam setiap menjalankan bisnis, termasuk didalam prinsip bagi hasil 
musyarakah. Berikut adalah manfaat dari musyarakah :

a. Jika mengalami keuntungan dari bisnis yang dijalankan tersebut baik, maka otomatis bank tentu akan mendapatkan hasil keuntungan yang tinggi juga sehingga pendapatan musyarakah meningkat.

b. Tidak wajib bagi bank untuk membayarkan secara tetap kepada nasabah.

c. Pengembalian akan disesuaikan dengan hasil yang didapat dari bisnis yang dikelola.

d. Bank tetap memilih bisnis dengan cara yang halal dan sesuai dengan syariat Islam, karena hasil keuntungan tersebut yang akan dibagi.

e. Musyarakah berbeda dengan prinsip bunga tetap yang ada di bank konvensional.

Adapun risiko yang akan dialami dalam melakukan akad musyarakah adalah sebagai berikut :

a. Nasabah yang melenceng dalam menggunakan dana tersebut, tidak sesuai dengan apa yang telah disepakati dalam akad.

b. Kesalahan yang dilakukan nasabah bisa disengaja ataupun tidak disengaja yang menyebabkan kerugian.

c. Nasabah yang tidak jujur dalam hasil bisnis tersebut, sehingga keuntungan yang akan dibagikan berbeda dengan keuntungan yang sebenarnya didapat.

\section{c. Penelitian Terdahulu}

Hasil-hasil penelitian terdahulu yang dilakukan oleh akademisi seperti Micco et al., (2007) melakukan penelitian dengan topik hubungan antara kepemilikan bank dan kinerja bank dengan sampel 179 negara. Hasil penelitian ini menemukan bahwa variabel bank milik pemerintah memiliki pengaruh negatif terhadap kinerja bank untuk negara berkembang dan tidak berpengaruh pada negara maju. Variabel bank pemerintah berpengaruh negatif pada negara-negara berkembang mengakibatkan tingkat pendapatan yang lebih rendah dan biaya operasional lebih tinggi dibandingkan dengan bank milik swasta. Flamini et al., (2009) meneliti pada 389 bank di Afrika selama periode 1998 hingga 2006. Hasil penelitian menemukan bahwa variabel bank milik pemerintah berpengaruh negatif terhadap ROA. Hasil ini menunjukkan bahwa bank milik pemerintah mengalami kerugian akibat pengelolaan bank yang tidak efisien dibandingkan dengan bank milik swasta. Fu dan Heffernan (2009) juga melakukan penelitian pada bank-bank di China selama periode 1985-2002. Hasil penelitian menunjukkan bahwa bank pemerintah lebih rendah memperoleh keuntungan dibandingkan dengan bank swasta. Kondisi ini disebabkan oleh pertumbuhan laba dan efisiensi yang lebih rendah dari bank swasta.

Iannotta et al., (2007) meneliti tiga bentuk kepemilikan bank di Eropa, yaitu bank swasta, bank campuran dan bank pemerintah. Sampel yang digunakan dalam penelitian ini sebanyak 181 bank di 15 negara Eropa selama periode 19992004. Hasil penelitian menunjukkan bahwa bank milik pemerintah mempunyai kinerja lebih rendah dibandingkan bank swasta. Hasil temuan ini menunjukkan bahwa bank pemerintah memiliki kekurangan modal sendiri dan modal kerja, jumlah dana pihak ketiga yang rendah, jumlah penyaluran kredit lebih kecil dan tingkat likuiditas yang tinggi sehingga mengakibatkan bank pemerintah tidak mampu bekerja secara optimal. Selain itu, Yu dan Neus (2009) melakukan penelitian dan menemukan bahwa bank pemerintah mempunyai kinerja yang lebih rendah dibandingkan dengan bank swasta pada negara Jerman dan Swiss. Hasil 
penelitian ini juga sejalan dengan peneliti Reaz (2005) yang menemukan bahwa bank pemerintah memiliki perputaran asset bank yang lebih rendah dibandingkan bank swasta sehingga kinerja bank pemerintah lebih rendah dari bank swasta di negara Bangladesh.

Berger et al., (2005) juga melakukan penelitian pada negara Argentina periode 1990-1999. Hasil penelitian menunjukkan bahwa bank milik pemerintah memiliki kinerja yang rendah sebelum adanya kebijakan privatisasi. Setelah privatisasi, kinerja bank-bank milik pemerintah meningkat secara signifikan. Penelitian yang dilakukan Omran (2007) pada 12 bank di Mesir selama tahun 1996-1999. Saat dilakukan penelitian banyak bank milik pemerintah diprivatisasi. Hasil penelitian menunjukkan bahwa bank milik pemerintah mempunyai kinerja dan efisiensi yang lebih rendah dibandingkan bank milik swasta.

Namun demikian terdapat hasil kajian yang berbeda dari hasil penelitian oleh Althanasoglou et al., (2008). Hasil penelitian menemukan bahwa bank swasta di Mesir memiliki kinerja yang lebih rendah dibandingkan dengan bank swasta akibat merger dan akuisisi yang dilakukan oleh bank tersebut. Sementara itu, hasil kajian Haddad et al., (2003) di Indonesia dan Chantapong (2005) di Thailand samasama menemukan bahwa variabel kepemilikan bank pemerintah tidak berpengaruh terhadap ROA dan ROE.

Rasio pembiayaan merupakan salah satu ukuran resiko bank. Pengaruh terhadap kinerja bank sangat sulit untuk ditentukan. Ini karena jika pendapatan pembiayaan tinggi menunjukkan bahwa bank telah berhasil menarik lebih banyak nasabah untuk memberikan pinjaman dan ini akan mempengaruhi tingkat keuntungan bank. Sementara itu, peningkatan pemberian pembiayaan juga menunjukkan bahwa berkemungkinan bank telah melonggarkan tingkat kualitas kredit yang dapat berakibat pada kredit macet. Beberapa hasil penelitian menunjukkan bahwa rasio pembiayaan atau kredit menunjukkan pengaruh positif seperti hasil penelitian Mamatzakis dan Remoundos (2003), Staikouras dan Wood (2005), Fernandez et al., (2005), Trivieri (2007), Mashharawi dan Al-Zu'bi (2009) dan Gul et al,. (2011). Sementara hasil penelitian Bashir (2003), Beck et al., (2005), Hassan dan Bashir (2005) dan Atemnkeng dan Joseph (2005) mendapati rasio pembiayaan atau kredit menunjukkan pengaruh negatif.

\section{METODE PENELITIAN}

Dalam penelitian ini adalah jenis data kuantitatif dan penelitian ini didapat dari laporan keuangan triwulan I tahun 2015 sampai dengan triwulan IV tahun 2018 Bank Umum Syariah pada website masing-masing bank dan memperoleh data yang diperlukan pada otoritas jasa keuangan.

Pengambilan sampel dengan metode purposive sampling Bank Syariah Mandiri, Bank Muamalat, Bank BRI Syariah, Bank BCA Syariah, Bank BNI Syariah dan Bank Bukopin Syariah. Metode yang digunakan untuk mengestimasi model regresi data panel, metode regresi linier berganda dengan persamaan sebagai berikut :

$Y=a+b_{1} X_{1}+b_{2} X_{2}+b_{3} X_{3}+e$

Keterangan :

$$
\begin{aligned}
& \mathrm{Y}: \text { Return On Asset } \\
& \mathrm{a}: \text { Konstanta } \\
& \mathrm{X}_{1}: \text { Pendapatan mudharabah } \\
& \mathrm{X}_{2}: \text { Pendapatan musyarakah } \\
& \mathrm{X}_{3}: \text { Dummy kepemilikan bank } \\
& \mathrm{e}: \text { Error }
\end{aligned}
$$

\section{HASIL DAN PEMBAHASAN}

\section{Hasil Pengujian Statistik Data}


Dependent Variable: ROA

Method: Least Squares

Date: 09/01/20 Time: 19:57

Sample: 196

Included observations: 96

\begin{tabular}{lrlrl}
\hline \hline \multicolumn{1}{c}{ Variable } & Coefficient & Std. Error & t-Statistic & Prob. \\
\hline \multicolumn{1}{c}{ C } & -0.147607 & 0.146134 & -1.010076 & 0.3151 \\
MUDHARABAH & 0.713401 & 0.197874 & 3.605333 & 0.0005 \\
MUSYARAKAH & -1.002054 & 0.153402 & -6.532212 & 0.0000 \\
KEPEMILIKAN BANK & 0.295213 & 0.254282 & 1.160969 & 0.2487 \\
\hline \hline R-squared & 0.517456 & Mean dependent var & $-2.08 \mathrm{E}-11$ \\
Adjusted R-squared & 0.501720 & S.D. dependent var & 1.000000 \\
S.E. of regression & 0.705889 & Akaike info criterion & 2.182057 \\
Sum squared resid & 45.84172 & Schwarz criterion & 2.288905 \\
Log likelihood & -100.7387 & Hannan-Quinn criter. & 2.225246 \\
F-statistic & 32.88534 & Durbin-Watson stat & 0.695736 \\
Prob(F-statistic) & 0.000000 & & \\
\hline \hline
\end{tabular}

Sumber : Data Olahan (2020)

Tabel diatas menunjukkan variabel struktur kepemilikan bank tidak berpengaruh terhadap ROA. Variabel pendapatan mudharabah berpengaruh positif sedangkan variabel pendapatan musyarakah berpengaruh negatif. Nilai Koefisien Determinasi $\mathrm{R}^{2}$ sebesar $51,75 \%$. Artinya nilai tersebut mampu menjelaskan sebesar $51,75 \%$ variasi dependen (profitabilitas). Sedangkan sisanya $58,25 \%$ dijelaskan oleh variabel lain.

Berdasarkan hasil dari pengujian statistik variabel struktur kepemilikan bank tidak berpengaruh terhadap ROA. Ini menunjukkan bahwa bentuk kepemilikan bank antara pemerintah dan swasta mempunyai kesamaan dalam kebijakan dalam pembiayaan sehingga tidak terdapat pengaruh terhadap kinerja bank. Hasil penelitian sejalan dengan penelitian Haddad et al., (2003) dan Chantapong (2005) mendapati bahwa kepemilikan bank tidak berpengaruh terhadap ROA.

Berdasarkan hasil dari pengujian statistik variabel pendapatan mudharabah berpengaruh positif dan signfikan terhadap profitabilitas Return On Asset (ROA). Pengaruh yang positif dan signifikan ini menunjukkan bahwa pendapatan penyaluran dana bagi hasil mudharabah, dengan keuntungan yang sudah disepakati diawal akad merupakan metode yang tepat sehingga nasabah peminjam dana berhasil mengelola usaha tersebut dengan baik. Sehingga dapat meningkatkan laba bank yang diperoleh dari keuntungan bagi hasil.

Hasil penelitian ini sejalan dengan dengan hasil penelitian Mamatzakis dan Remoundos (2003), Staikouras dan Wood (2005), Fernandez et al., (2005), Trivieri (2007), Mashharawi dan Al-Zu'bi (2009) dan Gul et al., (2011).

Berdasarkan hasil pengujian statistik variabel pendapatan musyarakah yang telah dilakukan, pendapatan musyarakah berpengaruh negatif dan signifikan terhadap profitabilitas bank umum syariah yaitu Return On Asset (ROA). Pengaruh negatif dari pendapatan musyarakah ini menunjukkan bahwa masih ada beberapa faktor yang terjadi karena resiko dari kegiatan usaha yang tidak pasti. Bank syariah juga belum sepenuhnya bisa mengendalikan asset yang dimiliki untuk meningkatkan laba bank. Meskipun dalam penyaluran dana musyarakah cukup tinggi, namun tidak 
menentukan bahwa profitabilitasnya juga tinggi karena usaha yang dilakukan dapat mengalami kegagalan, lalai dari kesalahan yang disengaja ataupun nasabah yang terikat kontrak tidak jujur atau melakukan kecurangan. Hasil penelitian sejalan dengan dengan hasil penelitian Bashir (2003), Beck et al., (2005), Hassan dan Bashir (2005) dan Atemnkeng dan Joseph (2005) mendapati rasio pembiayaan atau kredit menunjukkan pengaruh negatif.

\section{KESIMPULAN}

Tujuan penelitian ini untuk mengetahui pengaruh struktur kepemilikan dan pendapatan mudharabah dan pendapatan musyarakah terhadap kinerja keuangan yang diukur dengan Return On Asset (ROA) pada bank umum syariah di Indonesia. Pendapatan mudharabah memiliki pengaruh yang positif dan signifikan terhadap Return On Asset Bank Umum Syariah sedangkan pendapatan musyarakah memiliki pengaruh yang negatif dan signifikan terhadap Return On Asset Bank Umum Syariah. Namun secara simultan pendapatan mudharabah dan musyarakah berpengaruh positif dan signifikan terhadap kinerja keuangan bank syariah. Pengaruh pendapatan mudharabah dan musyarakah terhadap kinerja keuangan Bank Umum Syariah mampu menjelaskan dengan nilai Koefisien Determinasi $\mathrm{R}^{2}$ sebesar $51,75 \%$. Keterbatasan penelitian ini adalah jumlah variabel dan waktu penelitian sehingga untuk penelitian selanjutnya agar menambah beberapa variabel lain dan menambah periode waktu yang belum termasuk dalam penelitian ini.

\section{DAFTAR PUSTAKA}

Antonio, Muhammad Syafi'i. 2007. Bank Syariah: Dari Teori Ke Praktik. Gema Insani. Jakarta.

Atemnkeng, T., \& Joseph, N. 2005. Market Structure and Profitability Performance in The Banking
Industry of CFA Countries: The Case of Commercial Banks in Cameroon. Retrieved from www.jsd-africa.com/Jsda/Summer _2006/PDF.

Athanasoglou, P. P., Brissimis, S. N., \& Delis, M. D. 2008. Bank Specific, Industry Specific and Macroeconomic Determinants of Bank Profitability. Journal of International Financial Markets, Institutions and Money, 18(2), 121136.

Bashir, A. M. 2003. Determinants of Profitability in Islamic Banks: Some Evidence from Middle East. Islamic Economic studies, 11(1), 31-57.

Beck, T., Cull, R., \& Jarome, A. 2005. Bank Privatization and Performance: Empirical Evidence from Nigeria. Journal of Banking and Finance, 29, 2355-2379.

Berger A. N., Demirguc-Kunt A., Levine R., \& Haubrich J. G. 2004. Bank Concentration and Competition: An Evolution in The Making. Journal of Money, Credit and Banking, 36(3), 433-451.

Berger, A. N., Clarke, G. R., Cull, R., Klapper, L., \& Udell, G. F. 2005. Corporate Governance and Bank Performance: A Joint Analysis of The Static, Selection, And Dynamic Effects of Domestic, Foreign, And State Ownership. Journal of Banking and Finance, 29(8-9), 2179-2221.

Chantapong, S. 2005. Comparative study of Domestic and Foreign Bank Performance in Thailand: The Regression Analysis. Economic Change and Restructuring, 3, 63-83.

Cornett, M. M., Guo, L., Khaksari, S., \& Tehranian, H. 2010. The Impact of State Ownership on Performance Differences In Privately-Owned 
Versus State-Owned Banks: An International Comparison. Journal Financial Intermediation, 19, 74-94.

Fernandez, A. I., Fonseca, A. R., \& Gonzalez, F. 2005. Does Ownership Affect Banks Profitability? Some International Evidence. In E.Klein (8th ed.), Capital formation and banking (157-178). Nova Science Publishers, Inc.

Flamini, V., McDonald, C., \& Schumacher, L. 2009. The Determinants of Commercial Bank Profitability in Sub-Saharan Afrika. (IMF Working Paper 09/15). Washington, DC: International Monetary Fund . Retrieved from http://www.imf.org/ external/ pubs /ft/ wp/2009/wp0915.pdf.

Fu, X., \& Heffernan, S. 2009. The Effects of Reform on China's Bank Structure and Performance. Journal of Banking and Finance, 33, 39-52.

Gul, S., Irshad, F., \& Zaman, K. 2011. Factors Affecting Bank Profitability in Pakistan. The Romanian Economic Journal, 39, 61-87.

Hadad. M. D., Agus, S., Wini, P., M., \& Jony, H. 2003. Kajian mengenai Struktur Kepemilikan Bank di Indonesia. Bank Indonesia. Jakarta. Retrieved http://www.bi.go.id.

Hassan, M. K. \& Bashir, A. 2005. Determinants of Islamic Banking Profitability. Proceedings of the Economic Research Forum 10th Annual Conference, MarakeshMorocco.

Iannotta, G., Nocera, G., \& Sironi, A. 2007. Ownership Structure, Risk and Performance in the European Banking Industry. Journal of Banking and Finance, 31(7), 21272149.
La Porta , R., Lopez-de-Silanes, F., \& Shleifer, A. R. 2002. Government Ownership of Banks. Journal Finance, 57, 265-302.

Mamatzakis, E. C., \& Remoundos, P. C. 2003. Determinants of Greek Commercial Banks Profitability 1989-2000. SPOUDAI, 53(1), 8494.

Mashharawi, F.Y., \& Al-Zu'bi, K. 2009. The Determinants of Bank's Profitability: Evidence from the Jordanian Banking Sector (19922006). Jordan Journal of Business Administration, 5(3), 403-414.

Micco, A., Panizza, U., \& Yañez, M. 2004. Bank Ownership and Performance (IDB Working Paper No. 429). Inter-American Development Bank, Research Department. Retrieved November, 2004, from SSRN: http://ssrn.com/abstract $=1818718$ or http://dx.doi.org/10.2139/ssrn. 1818718

Micco, A., Panizza, U., Yanez, M. 2007. Bank Ownership and Performance: Does Politics Matter? Journal of Banking and Finance, 31, 219-241.

Omran, M. 2007. Privatization, State Ownership and Bank Performance in Egypt. World Development, 35(4), 714-733.

Reaz, M. 2005. Linking Corporate Governance and Bank Performance: Evidence from Bangladesh. Bangladesh: North South University. Retrieved from https://docs.google.com/viewer?.

Staikouras, C., \& Wood, G. 2005. The Determinants of Bank Profitability in Europe. International Business \& Economics Research Journal, 6(3), 56-68. 
2020, Jurnal Tabarru' : Islamic Banking and Finance 3 (2) : 86 - 94

Trivieri, F. 2007. Does Cross-Ownership Affect Competition? Evidence from The Italian Banking Industry. International Financial Markets, Institutions and Money, 17, 79-101.

Yu, P., \& Neus, W. 2009. Market Structure, Scale Efficiency and Risk As Determinants of German Banking Profitability. Retrieved from http://econstor.eu /bitstream/ 10419/22093/1/294.pdf. 